\title{
Saprobic conidial fungi associated with palm leaf litter in eastern Amazon, Brazil
}

\author{
JOSIANE S. MONTEIRO ${ }^{1}$, PRISCILA S.M. SARMENTO² and HELEN M.P. SOTÃO ${ }^{1}$ \\ ${ }^{1}$ Coordenação de Botânica, Museu Paraense Emílio Goeldi, \\ Av. Perimetral 1901, Caixa Postal 399, 66077-830 Belém, PA, Brazil \\ ${ }^{2}$ Instituto Tecnológico Vale - Desenvolvimento Sustentável, \\ Rua Boaventura da Silva, 955, Nazaré, 66055-090 Belém, PA, Brazil \\ Manuscript received on May 30, 2018; accepted for publication on September 13, 2018
}

\begin{abstract}
How to cite: MONTEIRO JS, SARMENTO PSM AND SOTÃO HMP. 2019. Saprobic conidial fungi associated with palm leaf litter in eastern Amazon, Brazil. An Acad Bras Cienc 91: e20180545. DOI 10.1590/00013675201920180545.
\end{abstract}

\begin{abstract}
Fungi play an important role in litter decomposition in forest ecosystems and are considered an undersampled group in the Amazon biome. This study aims to describe the composition, richness and frequency of species of conidial fungi associated with palm trees in an area of the Amapá National Forest, State of Amapá, Brazil. Palm leaf litter was collected from July 2009 to June 2010, incubated in moist chambers and examined for the presence of fungi. One hundred and seven species of conidial fungi were identified, in 79 genera and 25 families. As for the relative frequency of the species, the majority (94.4\%) was sporadic and occurred on leaflets. We report new records for South America (Chaetopsis intermedia, Chaetochalara laevis and Thysanophora verrucosa) and Brazil (Chloridium phaeosporum, Helminthosporiella stilbacea and Zygosporium geminatum), and 83 for the State of Amapá, while 15 are also new for the Brazilian Amazon. This study significantly increases the knowledge about the distribution of the fungal species in the Amazon biome, and emphasizes the importance of the conservation of these organisms particularly in view of the large number of sporadic species recorded.
\end{abstract}

Key words: asexual Ascomycota, Arecaceae, biodiversity, Flona Amapá, taxonomy.

\section{INTRODUCTION}

Conidial fungi include species that represent the asexual state of the life cycles of ascomycetes and basidiomycetes, occurring in several natural habitats and substrata. They are characterized by the development of conidia (propagules) of mitotic origin produced by conidiogenous cells on conidiophores (Seifert et al. 2011).

Conidial fungi are important components of the decaying process in the environment participating

Correspondence to: Josiane Santana Monteiro

E-mail: kiotobelbio2003@yahoo.com.br

ORCid: https://orcid.org/0000-0002-1717-9532 in nutrient cycling and breaking down complex polymers as cellulose, hemicellulose and lignin (Poll et al. 2010, Voříšsová and Baldrian 2013, Purahong et al. 2016). Several studies in tropical areas have recorded these fungi as the most frequent, especially in a succession process. They usually can sporulate quickly and dominate the earlier stages of succession, until being replaced by teleomorphs of Ascomycota and Basidiomycota (Duong et al. 2008, Kodsueb et al. 2008, Promputtha et al. 2017).

Intense recycling of superficial organic matter occurs in the Amazon forests, allowing the formation of a dense litter layer (Aprile et al. 2013, Grau et 
al. 2017). The participation of fungi present in the environment is essential for the maintenance of these ecosystems since they promote the mineralization and solubilization of nutrients retained in the organic matter, enriching the soil with nutrients that will be reused by plants (Peay et al. 2013, Lodge et al. 2014, Mueller et al. 2016).

In Brazil, the study of conidial fungi associated to the litter decomposition process has been investigated in the Caatinga and Atlantic forest biomes, where important works have been carried out and provided species lists, new records and the description of new species as presented in Forzza et al. (2010), Barbosa et al. (2013), and Santa Izabel and Gusmão (2018). For the Brazilian Amazon, taxonomic inventories of this group are still punctual, with a larger number of records for the state of Pará (Hernández-Gutiérrez et al. 2009, Monteiro et al. 2010, 2013, 2016a, Castro et al. 2011, 2012, Monteiro and Gusmão 2014). In Amapá, only 54 species of conidial fungi occurring on different substrates have been recorded so far (Silva and Minter 1995, Carmo et al. 2014, Monteiro et al. 2016b, 2017, CRIA 2018).

Studies have suggested the existence of approximately 16,000 plant species in the Amazon rainforest, among which palm trees stand out in number of plants and for the presence of some hyperdominant species (Steege et al. 2013). Several studies pointed out a high fungal diversity occurring in palm trees, with some genera limited to this group of plants (Hyde et al. 2007). Investigations of conidial fungi associated with the decomposition of palm leaves in the Brazilian Amazon have been restricted to three areas: the Caxiuanã National Forest (Hernández-Gutiérrez et al. 2009, Monteiro et al. 2010, 2013, Hernández-Gutiérrez 2013) and the Combu island in the Pará State (Castro et al. 2011, 2012) and the Amapá National Forest (Flona) in the Amapá State (Carmo et al. 2014, Monteiro et al. 2016b, 2017).
The Flona Amapá is a conservation unit comprised in the important biodiversity corridor of the state of Amapá and is located in the Guiana Shield sub-region, considered a priority area for the conservation of biodiversity (Capobianco et al. 2001, CI-Brasil 2009). This conservation unit has been threatened by anthropic pressures, especially the illegal exploitation of mineral resources, logging and clandestine exploitation of wildlife resources (ICMBio 2014).

Due to the lack of data about saprobic conidial fungi in the Brazilian Amazon, the present work aimed to analyze the composition, richness and frequency of conidial fungi species associated with decomposing palm leaves in the Flona Amapá and provide the list of the identified species and the new records for South America, Brazil, the Brazilian Amazon and the State of Amapá.

\section{MATERIALS AND METHODS}

The study was conducted within the Flona Amapá (51 53 '37' $\mathrm{W}$ and $\left.01^{\circ} 06^{\prime} 37^{\prime \prime} \mathrm{N}\right)$ between July 2009 and June 2010 . Ten $250 \times 4 \mathrm{~m}$ transects were established along pre-existing trails in the research site of the eastern Amazonian division of the Programa de Pesquisa em Biodiversidade (PPBio) (PPBio Amazônia Oriental 2018). In each transect, five individual palm trees were randomly selected at intervals of $50 \mathrm{~m}$. One sample of palm leaf litter was collected from each individual palm tree, including leaflets, petioles and rachis, and the material was stored in paper bags. Each palm tree was carefully marked for subsequent sampling.

Fifty samples from 50 palm trees were collected in each expedition (July and December of 2009), totaling 100 samples. Random samples (eight) were collected in a third expedition (July/2003), aiming to increase the list of conidial fungi in the study area.

The palm trees collected as substrates were identified by botanical technicians of the Herbarium João Murça Pires (MG) at the Emílio 
Goeldi Museum of Pará (MPEG). The palm tree species identified were: Attalea sp., Astrocaryum gynacanthum Mart., A. murumuru Mart., Bactris sp., Euterpe oleracea Mart., Geonoma sp., Oenocarpus sp., Socratea sp. and Syagrus sp.

In the laboratory, the samples were incubated in a damp chamber (5L plastic bags + moistened filter paper) at room temperature for 30 days. After this period, the samples were dried in an electric oven at average temperature between 50 and $60^{\circ} \mathrm{C}$. Reproductive structures of the fungi were observed under stereomicroscope and mounted on semipermanent slides with lacto-glycerol (distilled water + lactic acid + glycerin) and/or Amann blue (Neergaard et al. 2000).

To identify the species, structures of taxonomic importance, such as conidia, conidiogenous cells and conidiophores were observed and measured under a light microscope for comparison with descriptions in specialized literature. Fungal illustrations were prepared with a compound microscope equipped with a digital camera. Slides and dried samples were deposited in the Herbarium MG of the MPEG.

The statistical analyses used in this work included only the data collected in the first and second expeditions. In order to evaluate the sampling sufficiency and to estimate the richness in the study area and in the different substrates, the Chao 1, Chao 2, Jackknife 1 and 2 indices were applied, using the EstimateS 8.0 software (Colwell 2009).

The occurrence frequency of fungi $(F)$ was calculated according to the formula: $\mathrm{F}=\mathrm{n} \times 100 / \mathrm{N}$, where $\mathrm{n}=$ number of samples, in which a species was recorded, and $\mathrm{N}=$ total number of samples. The following frequency classes were established: $\mathrm{F} \leq 10 \%$ $=$ sporadic; $10<\mathrm{F} \leq 30 \%=$ infrequent; $30<\mathrm{F} \leq 70 \%$ $=$ frequent; and $\mathrm{F}>70 \%$ = very frequent (Dajoz 1983).

The richness of conidial fungi on the different substrates was compared by the Kruskal Wallis non-parametric analysis of variance (Zar 2009). In case of significant differences, the groups were compared on a one-pair-wise basis by the Dunn's test (Brower and Zar 1984). The tests were performed using the PAST version 3.18 software (Hammer et al. 2001).

To evaluate the differences between species composition of the three types of substrates, a nonmetric multivariate analysis of variance was performed with 10,000 permutations (One-way PERMANOVA) using the Bray-Curtis distance and the abundance of the species per substrate as the variable (Anderson 2001). A post-hoc PERMANOVA test was applied to check differences in species composition among substrates. In order to demonstrate the distribution of the species in the different substrates, the data were submitted to ordination by non-metric multidimensional scaling analysis (NMDS: non-metric multidimensional scaling) (Kruskal 1964). These multivariate analyzes were performed using the PRIMER V.6 statistical package (Clarke and Warwick 2001) and the application PERMANOVA+ for PRIMER (Anderson et al. 2008).

\section{RESULTS AND DISCUSSION}

\section{COMPOSITION AND RICHNESS}

In this study, 107 species of conidial fungi associated with palm leaf litter belonging to 79 genera, 25 families and four classes (Dothideomycetes, Eurotiomycetes, Leotiomycetes and Sordariomycetes) were identified. Among the species, 41 were genera incertae sedis (Table I).

Sordariomycetes (47) was the most represented class in richness, followed by Dothideomycetes (15). These are the largest classes among the ascomycetes described until present, including taxa that can occur in several types of environments and which play an important role in litter decomposition (Hyde et al.2013, Maharachchikumbura et al.2015). Members of Sordariomycetes and Dotideomycetes can degrade lignocellulosic materials and are very abundant in leaf litter (Melo et al. 2018). 
Chaetosphaeriaceae was the family with the highest number of species (15), followed by Dictyosporiaceae (7) and Nectriaceae (5) (Table I). Representants of these families are important biodegraders in the environment (Couturier et al. 2016, Melo et al. 2018). The genera with the highest number of species were Dictyosporium Corda (6), followed by Chloridium Link (4) and Zygosporium Mont. (4). Some species from these genera (Table I) are widely distributed in Brazil (CRIA 2018) and have already been reported in association with palm trees such as Euterpe edulis Mart. in São Paulo (Grandi 1999), and on E. oleracea, B. acanthocarpa Mart., B. hirta Mart., G. baculifera (Poith.) Kunth and O. distichus Mart. in Pará (Rodrigues 1994, Castro et al. 2012, Monteiro et al. 2013), and on A. murumuru, A. gynacanthum and Attalea sp. in Amapá (Monteiro et al. 2017).

Based on the sampling unit used in this study and according to the first- and second-order Chao indices and first- and second-order Jackknife indices, it was possible to reach around $80 \%$ and $93 \%$ of the estimated richness. These indices estimated, respectively, the values of $115,114,119$ and 134 species.

In this study, 84 species were observed in leaflets with estimated richness between 96 and 110 species. Petioles presented only 16 species (estimated richness between 26 and 33 species), while 24 species were present in rachises (estimated richness between 42 and 67 species). In the analysis of the relation between conidial fungi and substrate type, there was a significant difference of richness in leaflets compared to the other substrates $(\mathrm{H}=$ $33.42 \mathrm{p}<0.0005)$. The richness of petioles did not differ from that of rachises $(p=0.30)$ (Fig. 1).

These data demonstrate the need for more samplings, especially of petioles and rachises, which according to the estimators present greater richness than the values registered in this study, in agreement with the results presented by Yanna et al. (2001), Yanna and Hyde (2002) and Pinruan et al. (2007). These values can also be influenced by successional stages of the litter decomposition process, because of the variation in nutrient content during the succession (Yanna and Hyde 2002, Poll et al. 2010, Ma et al. 2014).

The composition of fungi species differed among the three substrates (PERMANOVA: F $=3.44 \mathrm{p}=0.0001)($ Petiole $\times$ Rachis: $\mathrm{t}=1.26$ $\mathrm{p}=0.007$; Petiole $\times$ Leaflet: $\mathrm{t}=2.08 \mathrm{p}=0.0001$; Rachis $\times$ Leaflet: $\mathrm{t}=2.06 \mathrm{p}=0.0001)$. This distinct species composition between the substrates can be better visualized in the NMDS analysis (Fig. 2). Tissues of palm trees have variable contents of cellulose, hemicelluloses and lignin (Fonseca et al. 2013) and anatomical differences (Pinnoi et al. 2006) that can influence the colonization of their leaflitter. Studies conducted with the palm trees Eleiodoxa conferta (Griff.) Burret (Pinnoi et al. 2006), Livistona chinensis (Jack.) R. Br. Ex. Mart. (Yanna et al. 2001) and Phoenix hanceana Naudin (Yanna and Hyde 2002) presented similar results in Asia, evidencing the existence of distinct fungal composition in the leaflet (rich in cellulose) and rachis and petiole (with more fibers and lignin).

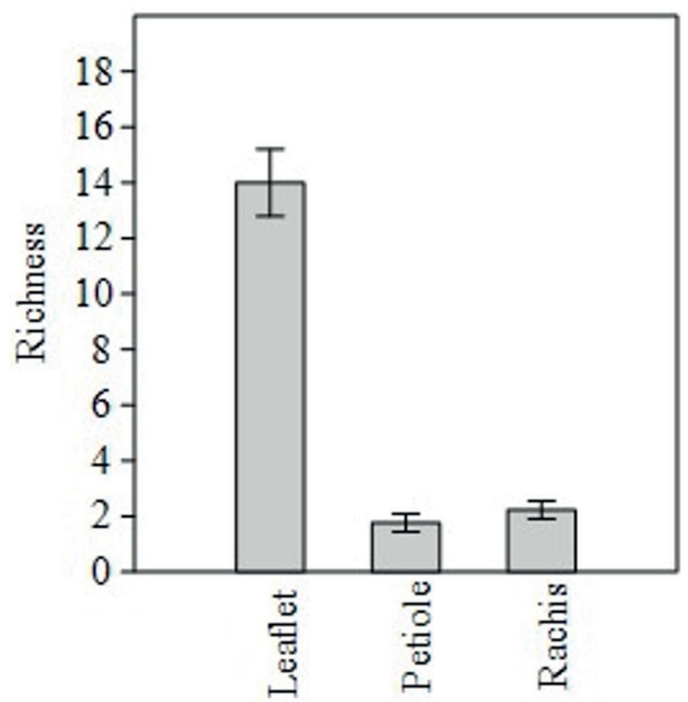

Figure 1 - Means and standard deviations of the richness of saprobic conidial fungi per palm leaf part. According to Dunn's test the richness of conidial fungi differs between leaflets and the other substrates $(p<0.05)$. 


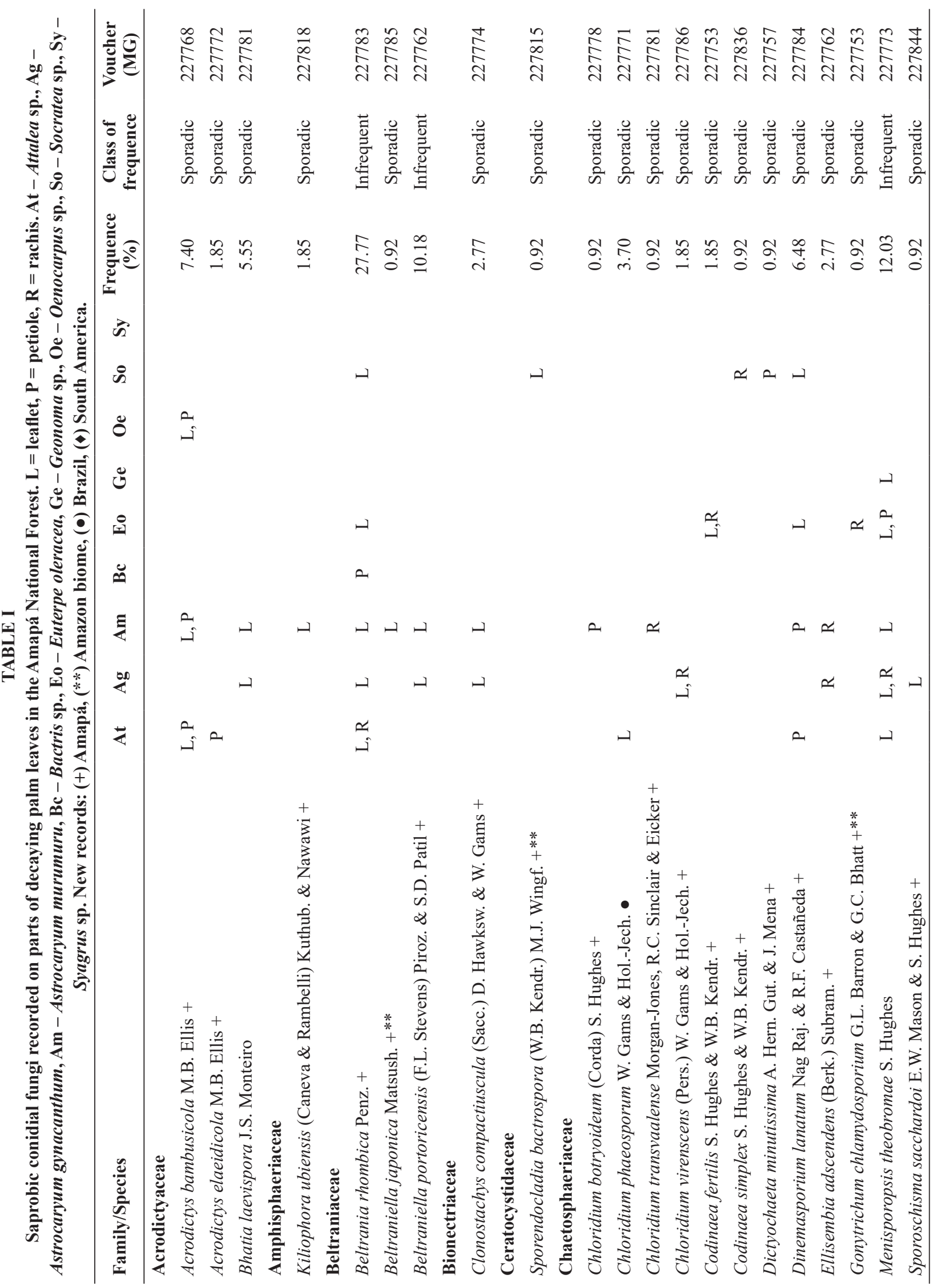




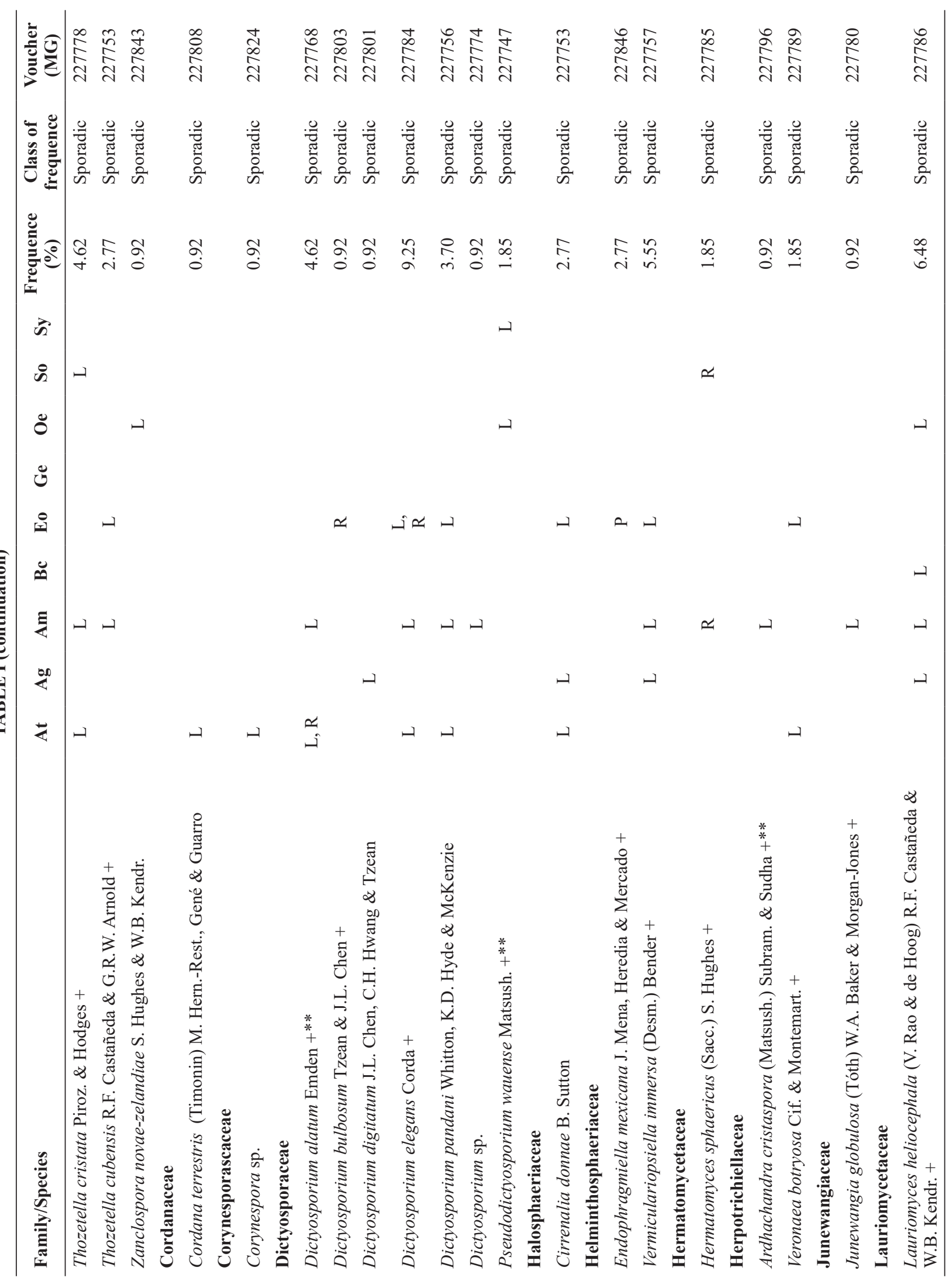




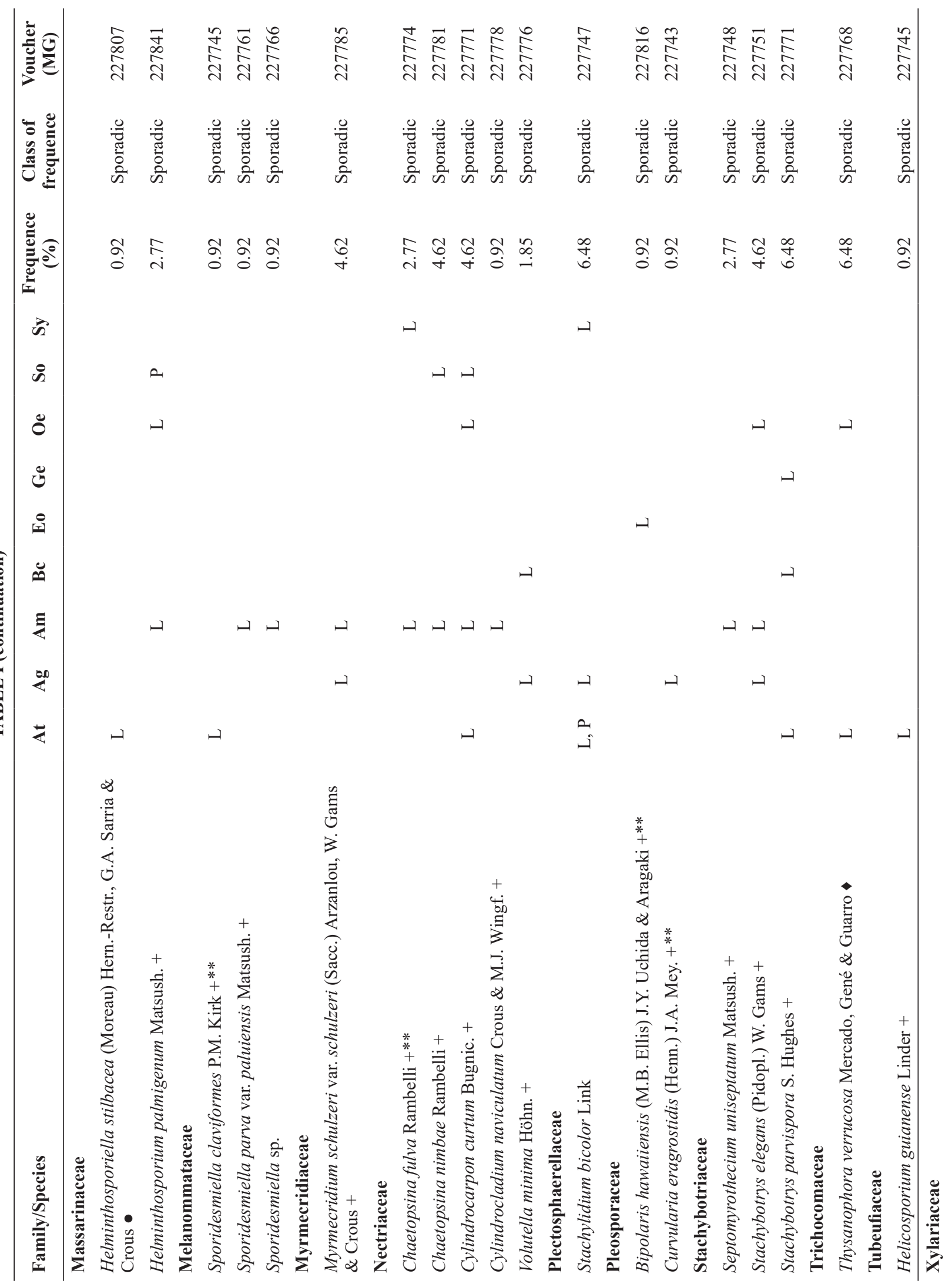




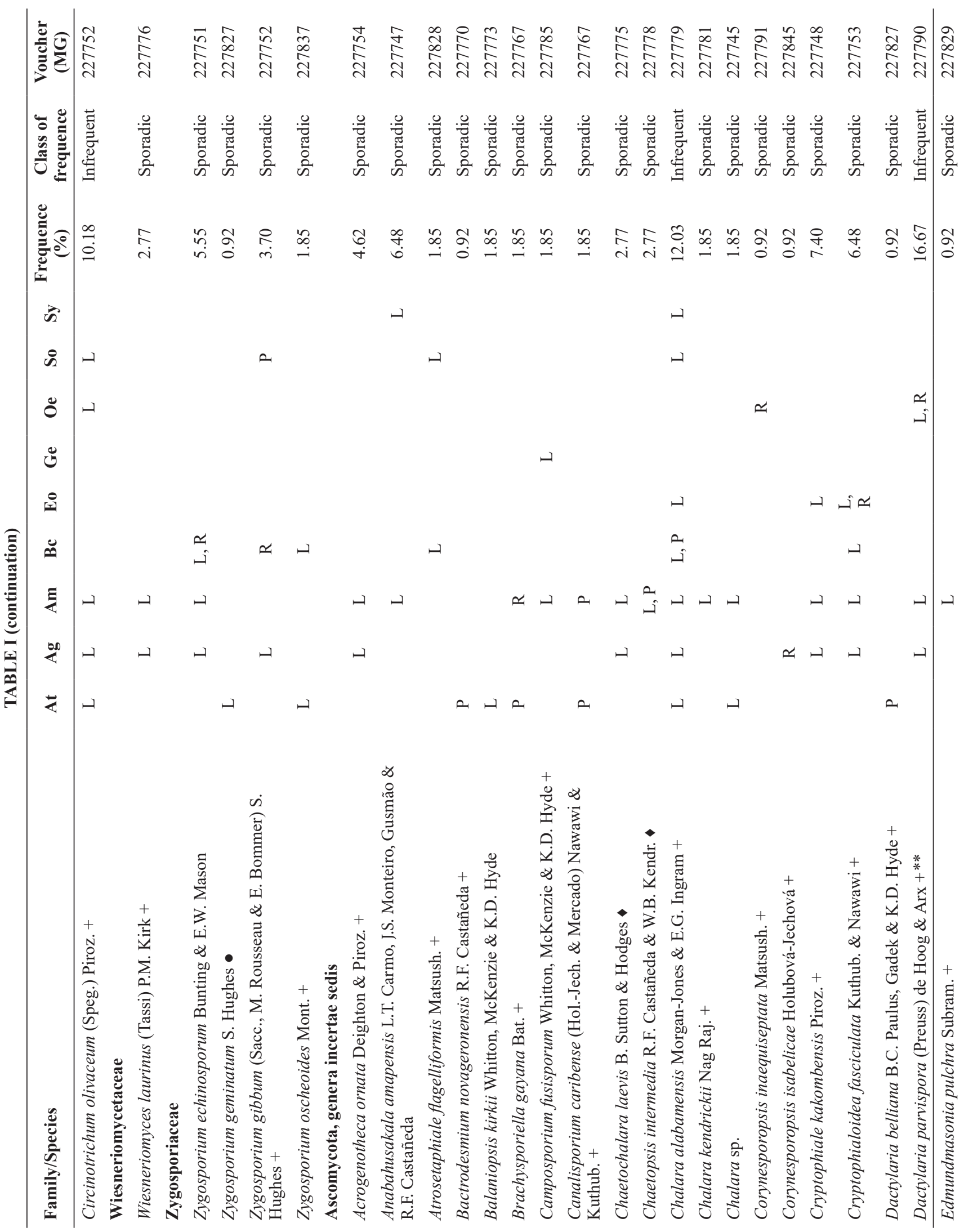




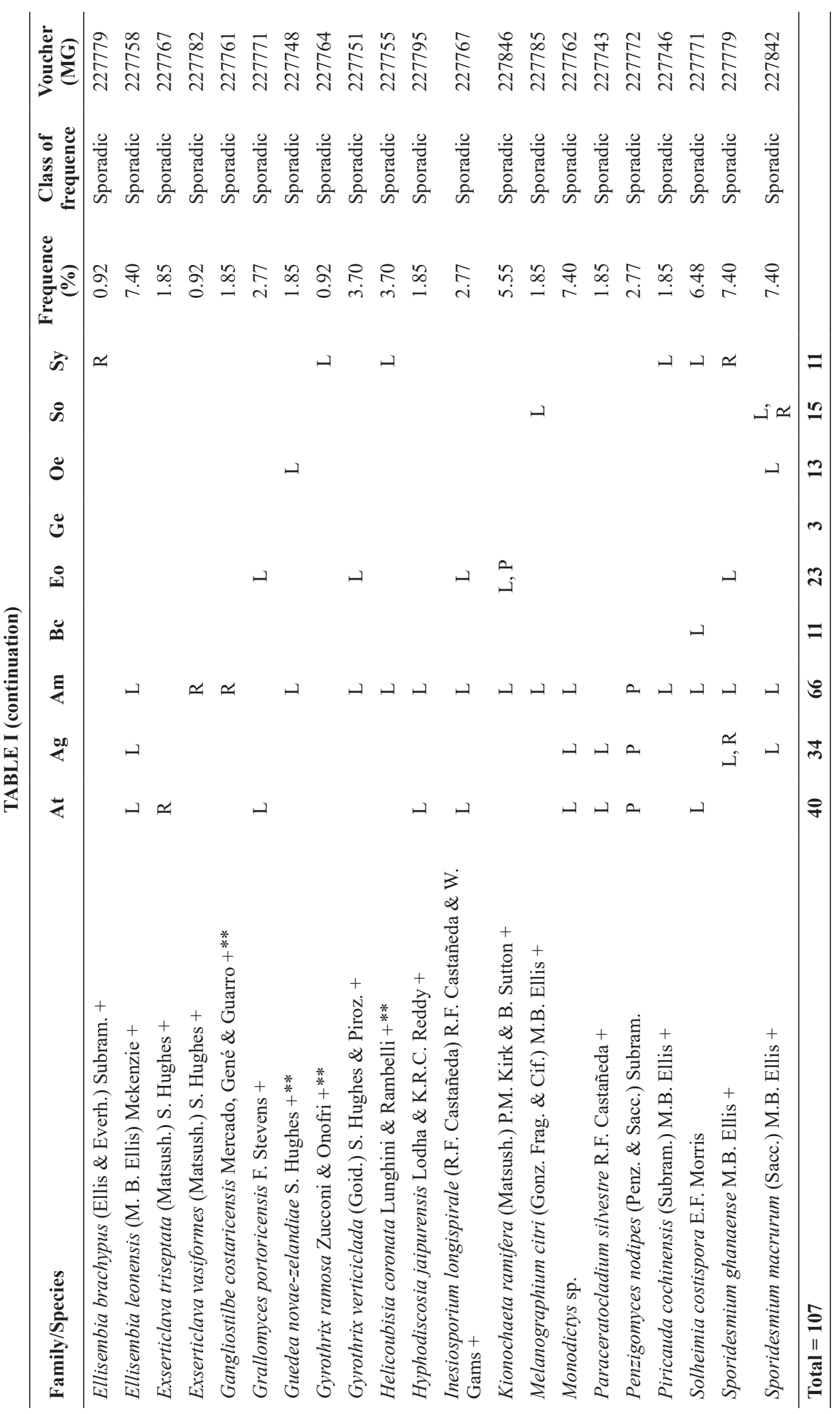


Resemblance: S17 Bray Curtis similarity

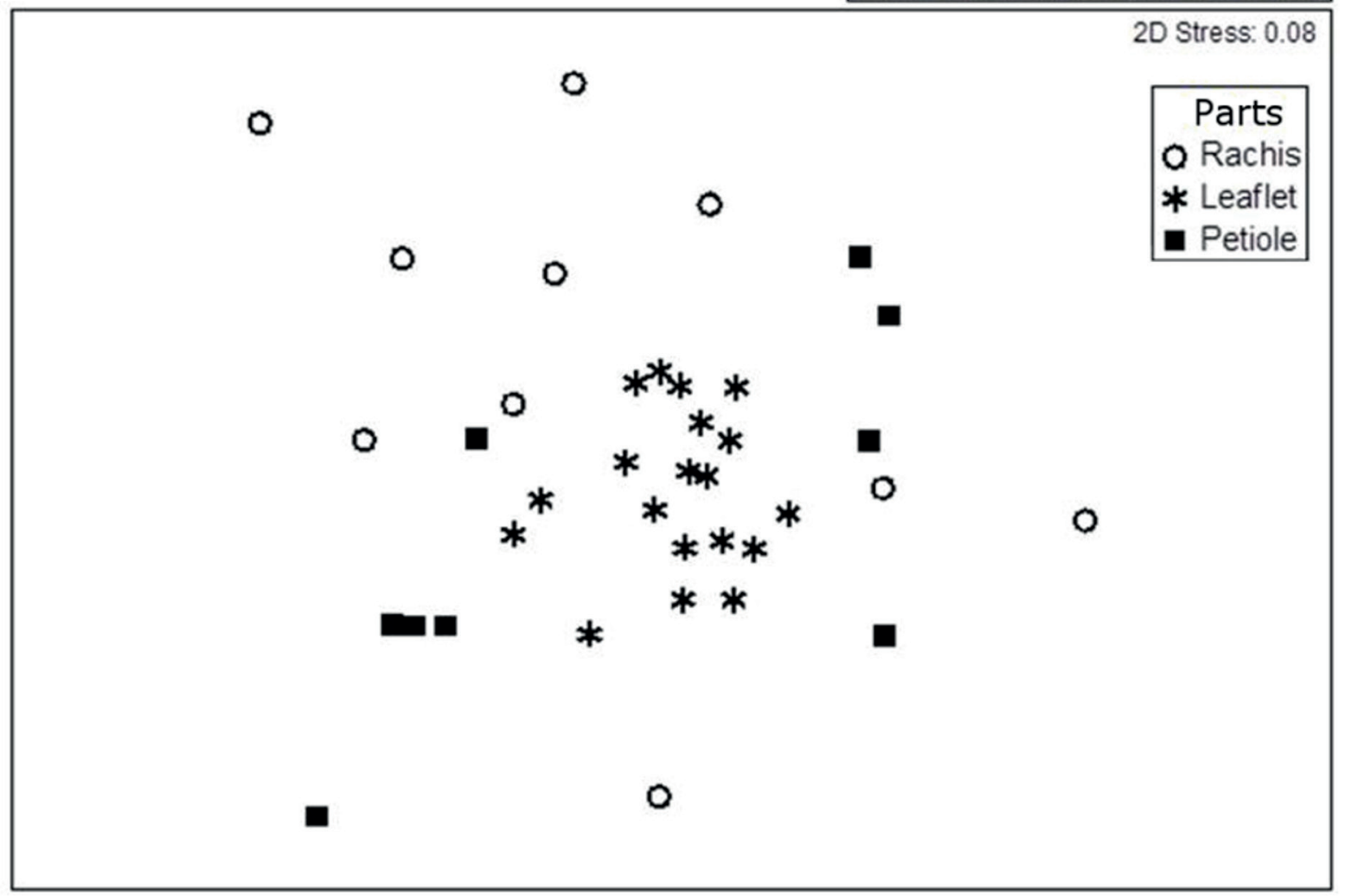

Figure 2 - Non-metric multidimensional scaling (NMDS) of the saprobic conidial fungi composition in the parts of palm leaves (2D Stress: 0.1).

Only Beltrania rhombica Penz., Menisporopsis theobromae S. Hughes and Zygosporium gibbum (Sacc. et al.) S. Hughes occurred on all the substrates analyzed. Canalisporium Nawawi \& Kuthub., Gangliostilbe Subram. \& Vittal, Hermatomyces Speg. and Penzigomyces Subram. occurred in petioles and rachises, confirming their occurrence in woody substrates (Seifert et al. 2011). The presence of fungi on specific tissues may be related to their enzymatic capability. Fungi with cellulolytic activities are frequently associated with leaves, while fungi with ligninolytic capability are more common in woody substrates (Osono and Takeda 2002, 2006).

The analysis of the occurrence of conidial fungi in palm trees showed that only Sporidesmium macrurum M.B. Ellis was frequently found in Arecaceae individuals. This species is widely distributed and has been reported in eleven palm tree species in the African, Asian and American continents (Yanna et al. 2001, Farr and Rossmann 2018). In Brazil, its occurrence is still restricted to the Amazon biome, precisely in the palm trees $E$. oleracea and A. gynacanthum (Castro et al. 2012, Monteiro et al. 2013).

As for the occurrence frequency in palm trees analyzed this study, $94.4 \%$ of the species were considered sporadic, while only $5.6 \%$ were infrequent (Table I). Studies carried out in Brazil have shown similar results in the areas of Atlantic forest (Santos et al. 2017). The high percentage of sporadic species in the studied area has been observed in other studies in palm trees and other plant species in tropical regions (Yanna et al. 2001, Pinruan et al. 2007, Seephueak et al. 2011). Factors as nutrient availability, water content, $\mathrm{pH}$ 
and anatomical peculiarities of the substrates may influence mycelial growth and affect the occurrence of fungi (Santana et al. 2005, Pinruan et al. 2007, Vorísková and Baldrian 2013).

The richness of conidial fungi recorded in palm trees in the Flona Amapá can be considered high in comparison with other studies carried out in Brazil: 57 species of endophytic fungi on Euterpe oleracea Mart. (Rodrigues 1994); 26 species of conidial fungi in leaf litter of E. edulis Mart. (Grandi 1999); 56 species in leaf litter of different palm trees (Hernández-Gutiérrez et al. 2009, Hernández-Gutiérrez 2013, Monteiro et al. 2010, 2013); and 57 conidial fungi on E. oleracea (Castro et al. 2011, 2012).

This study presents some preliminary observations on the saprobic conidial fungi on palm trees leaf litter from biome Amazon. Further studies will add new data. However, these preliminary data increase the knowledge of the distribution of fungi in the Amazon biome and demonstrate that taxonomic studies are indispensable tools for the knowledge of the mycobiota in unexplored areas and conservation units that are under strong anthropic pressure such as the Flona Amapá. Studies such as the present one endorses the importance of the conservation of these organisms, especially by providing evidence of a large number of species acting in the decomposition process in tropical forests.

\section{NEW OCCURRENCES}

The present study increased the number of species reported for the State of Amapá from 54 (Silva and Minter 1995, Carmo et al. 2014, Monteiro et al. 2016a, 2017, CRIA 2018) to 144. Ninety-seven species are reported for the first time for the Flona of Amapá, and among these, 83 are new records for the state of Amapá, while 15 are also new for the Brazilian Amazon (Table I).
The species Chaetopsis intermedia RF Castañeda \& WB Kendr., Chaetochalara laevis B. Sutton \& Hodges and Thysanophora verrucosa Mercado, Gené \& Guarro represent new records for South America, while Chloridium phaeosporum W. Gams \& Hol.-Jech., Helminthosporiella stilbacea (Moreau) Hern.-Restr., GA Sarria \& Crous and Zygosporium geminatum S. Hughes are new records for Brazil. We present the descriptions, information on geographical distributions, comments, and illustrations for these new records.

*Chaetochalara laevis B. Sutton \& Hodges, Nova Hedwigia 27: 343 (1976). Fig. 3a, b.

Setae simple, erect, straight, aseptate, smooth, dark brown, gradually tapering toward the apex, 294-330 × 5-7.5 $\mu \mathrm{m}$, basal region lageniform. Conidiogenous cells phialidic, 70-82.5 $\mu \mathrm{m}$ long, smooth, pale brown, arising solitary from the hyphae or aggregated in groups of 3-5 around the setae, collarette $42.5-57.5 \times 3.5-5 \mu \mathrm{m}$, venter 22.5$25 \times 7.5-10 \mu \mathrm{m}$. Conidia catenate, cylindrical with truncate ends, 1-septate, smooth, hyaline, 14-17 $\times$ 2-2.5 $\mu \mathrm{m}$.

Material examined: BRAZIL, Amapá, Ferreira Gomes, Floresta Nacional do Amapá, on decaying leaflets of A. gynacanthum Mart., 15 July 2009, J.S. Monteiro (MG 227775).

Distribution: Brazil (this study), Cuba (Delgado-Rodriguez et al. 2003), Malaysia (Sutton and Hodges 1976).

Chaetochalara B. Sutton \& Piroz. currently presents nine accepted species that can be differentiated from each other based on the morphology and dimensions of setae, phialides and conidia (Silva et al. 2015). The material analyzed had much larger setae (up to $330 \mu \mathrm{m}$ long), while phialides and conidia were smaller than those recorded by Sutton and Hodges (1976) in the Malaysian material $(16.5-19 \times 2.5-3 \mu \mathrm{m})$. This 
record represents the first occurrence of $C$. laevis in South America.

*Chaetopsis intermedia R.F. Castañeda \& W.B. Kendr., Univ. Waterloo Biol. Ser. 35: 18 (1991). Fig. 3c-e.

Conidiophores macronematous, mononematous, simple, erect, straight or slightly flexuous, solitary, setiform, septate, smooth, sometimes producing branches, tapering toward the apex, brown to dark brown in the base, paler toward the apex, 175-245 $\times$ 5-7.5 $\mu \mathrm{m}$. Conidiogenous cells monophialidic or polyphialidic, discrete, lageniform or subulate, with a collarette funnel-shaped, pale brown, 10$23.5 \times 3.5-5 \mu \mathrm{m}$. Conidia falcate or fusiform, acute in each end, slightly curved, (0-)1-septate, smooth, hyaline, 17-21 $\times 1.5-2 \mu \mathrm{m}$, produced in mucilaginous masses.

Material examined: BRAZIL, Amapá, Ferreira Gomes, Floresta Nacional do Amapá, on decaying leaflets of A. murumuru Mart., 15 July 2009, J.S. Monteiro (MG 227778).

Distribution: Brazil (this study), Cuba (Castañeda-Ruiz and Kendrick 1991).

Chaetopsis Grev. has ten species accepted to date that occur in decomposing wood, leaves and bark (Seifert et al. 2011). Chaetopsis intermedia shows similarities with $C$. cubensis Castañeda, however differs from it for the presence of tapered conidia at each end rather than lunate, truncated at the base and rounded at the apex (Castañeda-Ruiz 1985). The material examined presented slightly smaller conidia than those described by CastañedaRuiz and Kendrick (1991) for Cuban material (21$23 \times 1-2 \mu \mathrm{m})$. This is the first report of this species in South America.

*Chloridium phaeosporum W. Gams \& Hol.-Jech., Studies in Mycology 13: 27 (1976). Fig. 3f-h.

Conidiophores macronematous, mononematous, simple, erect, straight or slightly flexuous, septate, smooth, brown, paler toward the apex, 55-72.5 $\times$ 2.5-3.5 $\mu \mathrm{m}$. Conidiogenous cells monophialidic, integrated, terminal, cylindrical, smooth, pale brown, $12-23 \times 2-3 \mu \mathrm{m}$, collarettes funnel-shaped, 1-1.5 $\mu \mathrm{m}$ wide, with 1-2 percurrent extensions. Conidia ellipsoidal to oblong, unicellular, obtuse in the apex, with dark basal hilum, smooth, pale brown, $4-5 \times 1.5-2 \mu \mathrm{m}$, produced in mucilaginous masses.

Material examined: BRAZIL, Amapá, Ferreira Gomes, Floresta Nacional do Amapá, on decaying leaflets of Attalea sp., 15 July 2009, J.S. Monteiro (MG 227771).

Distribution: South Africa, China (Wu and Zhang 2013), Brazil (this study), French Guiana (Petrini and Dreyfuss 1981), Mexico (Heredia et al. 2013), Peru (Matsushima 1993), Puerto Rico (Polishook et al. 1996).

Chloridium Link presents about 30 accepted species, with teleomorphs included in Chaetosphaeria Tul.\& C. Tul. (Chaetosphaeriaceae, Chaetosphaeriales) (Seifert et al. 2011, MycoBank 2018). Chloridium virescens var. virescens (Pers.) W. Gams \& Hol.-Jech. is the closest species to $C h$. phaeosporum, but has hyaline and smaller conidia (3.2-4 $\times 2-2.5 \mu \mathrm{m})$ lacking a pigmented basal hilum (Gams and Holubová-Jechová 1976). Chloridium xigazense Y.M. Wu \& T.Y. Zhang is also similar, but has frequently proliferating conidiogenous cells and hyaline conidia $(3-5 \times 2-2.5 \mu \mathrm{m})$ with a dark hilum (Wu and Zhang 2013). The material analyzed meets the description of Gams and Holubová-Jechová (1976), except for the presence of longer conidiophores $(55-72.5 \times 2.5-3.5 \mu \mathrm{m})$. The Brazilian specimens are morphologically more similar to the specimens described by MorganJones et al. (1991), except by the monophialidic conidiogenous cells. This species is restricted to tropical environments until present, and this is the first report for Brazil. 


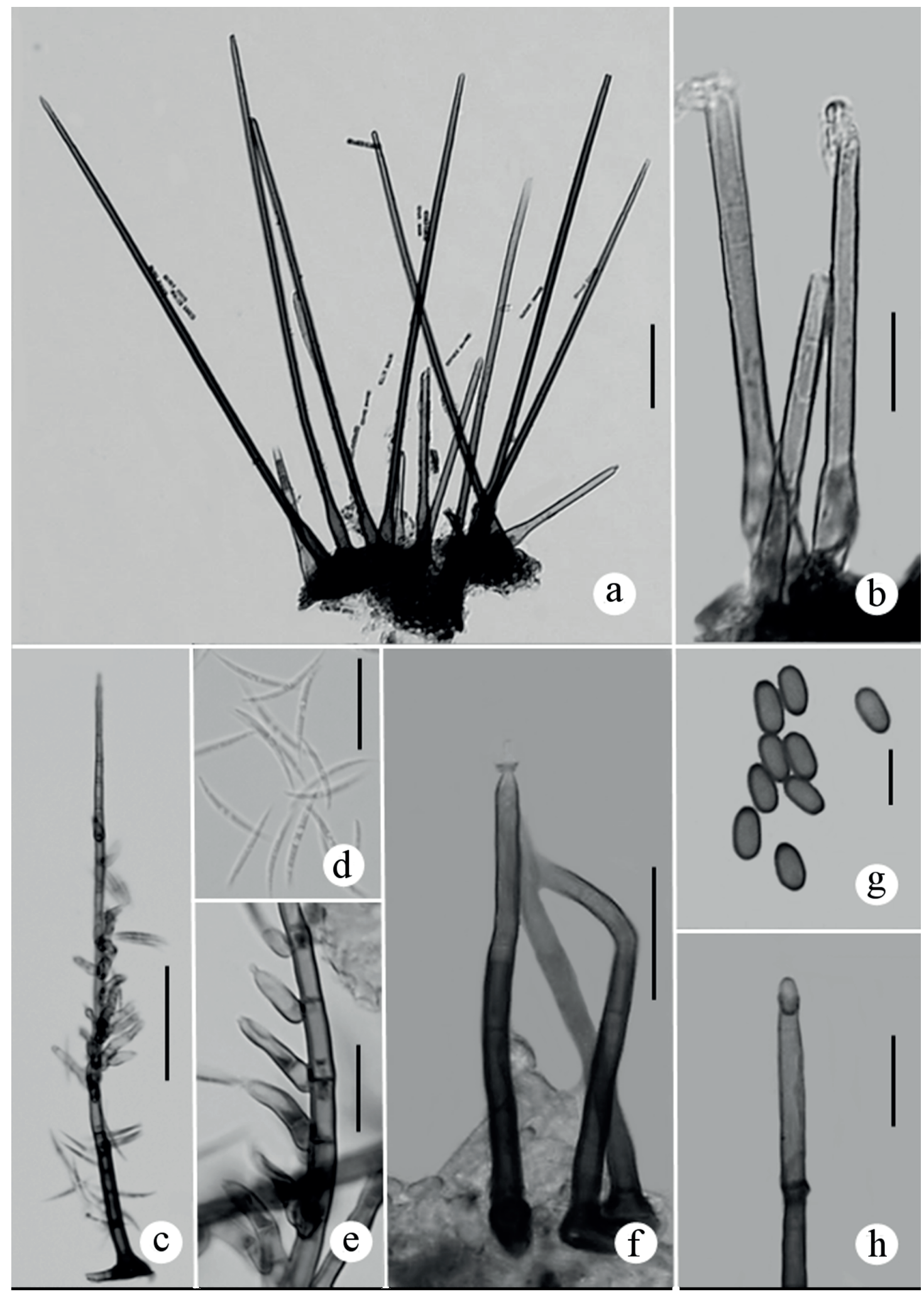

Figure 3 - a, b. Chaetochalara laevis. a. Setae, phialides and conidia, b. Phialides. c-e. Chaetopsis intermedia. c. Conidiophore, d. Conidia, e. Detail of conidiogenous cells. f-h. Chloridium phaeosporum. f. Conidiophores, g. Conidia, h. Detail of phialide. Bars: a, c $(50 \mu \mathrm{m}) ; \mathbf{d}-\mathbf{f}(20 \mu \mathrm{m}) ; \mathbf{b}, \mathbf{h}(10 \mu \mathrm{m}) ; \mathbf{g}(5 \mu \mathrm{m})$. 
*Helminthosporiella stilbacea (Moreau) Hern.Restr., G.A. Sarria \& Crous, Persoonia 36: 437 (2016). Fig. 4a-d.

Conidiomata synnematous, solitary, erect, straight or slightly flexuous, cylindrical, compacted, brown to dark brown, 450-675 $\times 22.5-25 \mu \mathrm{m}$, and composed of parallel, septate longitudinal hyphae. Hyphae unbranched, smooth, brown to dark brown. Conidiophores simple, straight or slightly flexuous, cylindrical, septate, smooth, brown, paler toward the apex, 4-5 $\mu \mathrm{m}$ wide. Conidiogenous cells monoor polytretic, integrated, determinate, terminal, cylindrical, 21.5-42.5 × 4.5-5 $\mu \mathrm{m}$. Conidia shortly catenate, easily disarticulating, acrogenous, straight or slightly curved, subcylindrical to obclavate, 4-8-distoseptate, smooth, rarely with striate-wall in the basal part of conidia, brown, with dark brown basal hilum, 42-120 × 6-8 $\mu \mathrm{m}$.

Material examined: BRAZIL, Amapá, Ferreira Gomes, Floresta Nacional do Amapá, on decaying leaflets of Attalea sp., 16 December 2009, J.S. Monteiro (MG 227807).

Distribution: Brazil (this study), Colombia (Crous et al. 2016), Congo, Ghana, Guinea, Honduras, Malaysia, Sao Tome and Principe, Sierra Leone, Sudan, Tanzania, Venezuela, Zambia [Farr and Rossman 2018, as Exosporium stilbaceum (Moreau) M.B. Ellis].

Helminthosporiella Hern.-Restr., G.A. Sarria $\&$ Crous (Massarinaceae) was proposed by Crous et al. (2016) as a new combination to Cercospora palmicola f. stilbacea Moreau (Moreau 1947), and with H. stilbacea (Moreau) Hern.-Restr., G.A. Sarria \& Crous as the type species. This genus is morphologically similar to Corynespora Güssow and Helminthosporium Link for the presence of tretic conidiogenesis and distoseptate conidia. However, the conidiogenous cells in Corynespora are monotretic and perpendicular with conidia in chains, whereas Helminthosporium has polytretic conidiogenous, terminal and intercalary cells and solitary conidia. The analyzed material presented larger conidia than those described by Hughes [1952, as H. stilbaceum (Moreau) S. Hughes] $(40-90 \times 9-10 \mu \mathrm{m})$, Ellis (1961, as E. stilbaceum) $(35-104 \times 7-12 \mu \mathrm{m})$ and Crous et al. (2016) (26$83 \times 7-10 \mu \mathrm{m})$. The Brazilian specimen presented smooth conidia and striate-walls in the basal part in some conidia only. These differences observed between the conidia of the Brazilian material and the material described by Crous et al. (2016) can represent a response to particularities of environment and substrate. This is the first record of this genus for Brazil and its distribution is until present limited to tropical environments.

*Thysanophora verrucosa Mercado, Gené \& Guarro, Mycotaxon 67: 419 (1998). Fig. 4e, f.

Conidiophores macronematous, mononematous, erect, straight or slightly flexuous, branched, septate, verrucose, greyish brown, 375-585 × 6-8.5 $\mu \mathrm{m}$; branches penicillate usually paler, verrucose, with groups of 3-4 phialides. Conidiogenous cells monophialidic, discrete, determinate, lageniform, verrucose, pale brown or grayish brown, 14.5-21 $\times 2.5-3 \mu \mathrm{m}$. Conidia catenate, in short basipetal chains, ellipsoidal or ovoidal, unicellular, truncate at the ends, smooth, pale brown to grayish brown, $5-6 \times 1.5-2.5 \mu \mathrm{m}$.

Material examined: BRAZIL, Amapá, Ferreira Gomes, Floresta Nacional do Amapá, on decaying leaflets of Oenocarpus sp., 15 December 2009, J.S. Monteiro (MG 227794).

Distribution: Brazil (this study), Cuba (Mercado-Sierra et al. 1998).

Thysanophora W.B. Kendr. presents eight accepted species in Trichocomaceae (Eurotiales), which can be differentiated by conidiophore and conidia morphology (Mercado-Sierra et al. 1998, Seifert et al. 2011). Thysanophora verrucosa possesses conidiophores and warty phialides that easily distinguish it from other species of the 


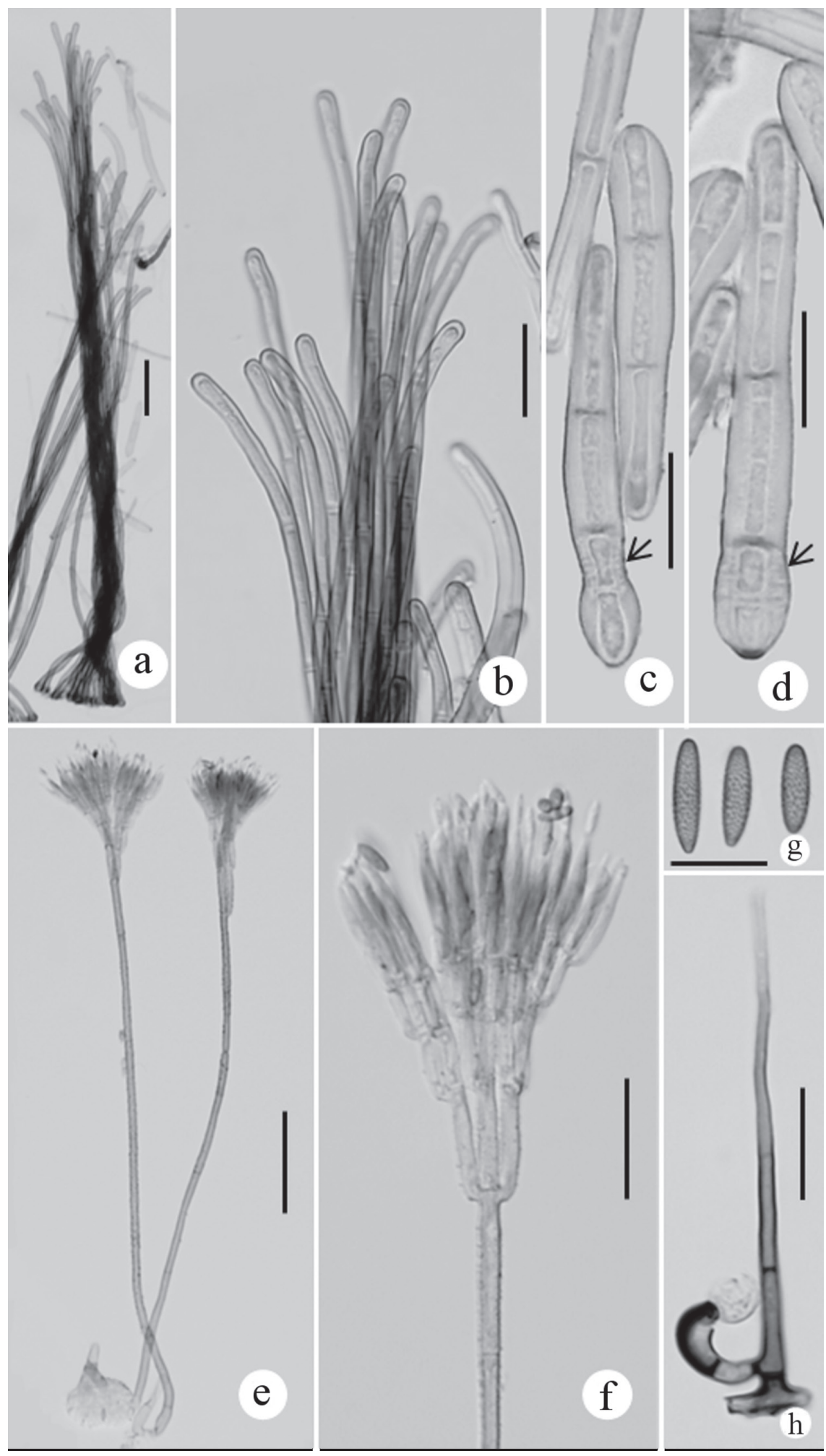

Figure 4 - a-d. Helminthosporiella stilbacea. a. Synnemata, b. Conidiogenous cells, c, d. Conidia with presence of wall-striate in the basal part (arrow). e, f. Thysanophora verrucosa. e. Conidiophores, f. Conidiogenous cells and conidia. g, h. Zygosporium geminatum. g. Conidiophore, h. Conidia. Bars: a $(50 \mu \mathrm{m}) ; \mathbf{b}-\mathbf{g}(20 \mu \mathrm{m})$. 
genus that have smooth walls (Mercado-Sierra et al. 1998). The material in this study showed conidiophores that were larger (up to $585 \mu \mathrm{m}$ long) than those recorded by Mercado-Sierra et al. (1998) $(240-450 \times 3-4.5 \mu \mathrm{m})$. This is the first report for South America.

*Zygosporium geminatum S. Hughes, Mycological Papers 44: 5 (1951). Fig. 4g, h.

Conidiophores macronematous, mononematous, setiform, simple, erect, straight, septate, tapered from the base toward the apex, smooth, pale brown, supporting a only vesicle laterally on a support cell above the base, $60-82.5 \times 3.5-5 \mu \mathrm{m}$, cylindrical to clavate apical cell. Vesicular cell swollen, upwardly curved, smooth, dark brown, 12.5-16 $\times$ 5-6 $\mu \mathrm{m}$, arising from a stalk cell cylindrical, smooth, brown. Conidiogenous cells monoblastic, discrete, determinate, oval to subspherical, two per vesicle, smooth, hyaline to pale brown. Conidia solitary, ellipsoidal, unicellular, both ends rounded, verrucose with flat warts, brown, 17.5-25 × 5-6 $\mu \mathrm{m}$.

Material examined: BRAZIL, Amapá, Ferreira Gomes, Floresta Nacional do Amapá, on decaying leaflets of Attalea sp., 17 December 2009, J.S. Monteiro (MG 227827).

Distribution: Brazil (this study), Ivory Coast (Hughes 1951), Ghana, Uganda, Mexico, Venezuela (Martínez-Rivera et al. 2014).

Zygosporium Mont. currently has 21 accepted species (MycoBank 2018) that can be distinguished by the morphology of conidiophores, vesicles, conidiogenous cells and conidia (Whitton et al. 2003). The examined material met Hughes' (1951) description, except only for the presence of smaller conidia $(17.5-25 \times 5-6 \mu \mathrm{m} v s .20-30 \times 8-11 \mu \mathrm{m})$. This is the first report of the species for Brazil and its distribution is still restricted to tropical environments.

\section{ACKNOWLEDGMENTS}

We thank the Museu Paraense Emílio Goeldi, Laboratório de Micologia da Universidade Federal do Pará, Instituto de Pesquisas Científicas e Tecnológicas do Estado do Amapá and the ICMBio for the infrastructure offered to carry out this work, and the Programa de Pesquisa em Biodiversidade (PPBio) - Amazônia and the Conselho Nacional de Desenvolvimento Científico e Tecnológico (CNPq) for funding this research through the projects approved via the SISBIOTA and UNIVERSAL. The first author thanks the CNPq for the scholarship of the Programa de Capacitação Institucional (PCI) of the Museu Paraense Emílio Goeldi (MPEG).

\section{AUTHOR CONTRIBUTIONS}

JSM, PSMS and HMPS wrote the manuscript; PSMS conducted the data analysis; JSM prepared the descriptions and figures of new occurrences; all authors contributed toward interpreting the results and critically revised the manuscript and approved the final version.

\section{REFERENCES}

ANDERSON MJ, GORLEY RN AND CLARKE KR. 2008. PERMANOVA+ for PRIMER: guide to software and statistical methods. Plymouth: PRIMER-E, 274 p.

ANDERSON MJA. 2001. New method for non-parametric multivariate analysis of variance. Austral Ecol 26(1): 3246.

APRILE F, SIQUEIRA GW, DARWICH AJ, SANTOS VC AND RIBEIRO AA. 2013. Concentration of nutrients in litter as a function of soil type, climate and forest composition in Amazon. Agr Sci Dev 2(8): 59-66.

BARBOSA FR, RAJA HA, SHEARER CA AND GUSMÃO LFP. 2013. Some freshwater fungi from the Brazilian semiarid region, including two new species of hyphomycetes. Cryptogamie Mycol 34(3): 243-258.

BROWER JE AND ZAR JH. 1984. Field and laboratory methods for general ecology. Iowa: W.C. Brown Company Publishers, $226 \mathrm{p}$.

CAPOBIANCO JPR, VERÍSSIMO A, MOREIRA A, SAWYER D, SANTOS I AND PINTO LP. 2001. Biodiversidade da Amazônia brasileira: avaliação e ações prioritárias para a conservação, uso sustentável e repartição de benefícios. São Paulo: Estação Liberdade Instituto Socioambiental, $540 \mathrm{p}$.

CARMO LT, MONTEIRO JS, GUSMÃO LFP, SOTÃO HMP, GUTIÉRREZ AH AND CASTAÑEDA-RUIZ RF. 2014. 
Anabahusakala, a new genus from the Brazilian Amazon rainforest. Mycotaxon 127: 11-15.

CASTAÑEDA-RUIZ RF. 1985. Deuteromycotina de Cuba. Hyphomycetes III. Havana: Instituto de Investigaciones Fundamentales em Agricultura Tropical "Alejandro de Humboldt", $42 \mathrm{p}$.

CASTAÑEDA-RUIZ RF AND KENDRICK B. 1991. Ninetynine conidial fungi from Cuba and three from Canada. University of Waterloo Biolological Series 35: 1-132.

CASTRO CC, HERNÁNDEZ-GUTIÉRREZ A AND SOTÃO HMP. 2011. Novos registros de fungos anamorfos (hifomicetos) para o Neotrópico e América do Sul. Rev Bras Bot 34(4): 515-521.

CASTRO CC, HERNÁNDEZ-GUTIÉRREZ A AND SOTÃO HMP. 2012. Fungos conidiais em Euterpe oleracea Mart. (açaizeiro) na Ilha do Combu, Pará-Brasil. Acta Bot Bras 26(4): 761-771.

CI - BRASIL. 2009. Corredor da Biodiversidade do Amapá. Belém: Conservação Internacional, 42 p.

CLARKE KR AND WARWICK RM. 2001. Change in marine communities: an approach to statistical analysis and interpretation. 2nd ed., Plymouth: PRIMER-E Ltd, 172 p.

COLWELL R. 2009. EstimateS: Statistical estimation of species richness and shared species from samples. Version 8.2. Available at: http://viceroy.eeb.uconn.edu/EstimateS. Accessed on February 20, 2018.

COUTURIER M, NAVARRO D, FAVEL A, HAON M, LECHAT C, LESAGE-MEESSEN L, CHEVRET D, LOMBARD V, HENRISSAT B AND BERRIN JG. 2016. Fungal secretomics of ascomycete fungi for biotechnological applications. Mycosphere 7(10): 15461553.

CRIA - CENTRO DE REFERÊNCIA E INFORMAÇÃO AMBIENTAL. 2018. SpeciesLink. Disponível em: http:// www.splink.org.br/index. Acesso em 24 de abril de 2018.

CROUS PW ET AL. 2016. Fungal Planet description sheets: 400-468. Persoonia 36: 316-458.

DAJOZ R. 1983. Ecologia geral. Petrópolis: Vozes, 472 p.

DELGADO-RODRIGUEZ G, MENA-PORTALES J AND MERCADO-SIERRA A. 2003. Nuevos registros de hifomicetos (hongos anamorficos) en las alturas de Trinidad (Cuba). Bol Soc Micol Madr 27: 49-54.

DUONG LM, MCKENZIE EHC, LUMYONG S AND HYDE KD. 2008. Fungal succession on senescent leaves of Castanopsis diversifolia in Doi Suthep-Pui National Park, Thailand. Fungal Divers 30: 23-36.

ELLIS M. 1961. Dematiaceous hyphomycetes III. Mycol Papers 82: 1-55.

FARR DF AND ROSSMAN AY. 2018. Fungal Databases, Systematic Mycology and Microbiology Laboratory, ARS, USDA. Available at: http://nt.ars-grin.gov/ fungaldatabases/. Accessed on April 15, 2018.
FONSECA AS, MORI FA, TONOLI GHD, SAVASTANO JUNIOR H, FERRARI DL AND MIRANDA IPA. 2013. Properties of an Amazonian vegetable fiber as a potential reinforcing material. Ind Crops Prod 47: 43-50.

FORZZA RC ET AL. 2010. Catálogo de Plantas e Fungos do Brasil. Rio de Janeiro: Instituto de Pesquisas Jardim Botânico do Rio de Janeiro/Andréa Jakobsson Estúdio, $847 \mathrm{p}$.

GAMS W AND HOLUBOVÁ-JECHOVÁ V. 1976. Chloridium and some other dematiaceous hyphomycetes growing on decaying wood. Stud Mycol 13: 1-99.

GRANDI RAP. 1999. Hifomicetos decompositores do folhedo de Euterpe edulis Mart. Hoehnea 26(1): 87-101.

GRAU O ET AL. 2017. Nutrient-cycling mechanisms other than the direct absorption from soil may control forest structure and dynamics in poor Amazonian soils. Sci Rep 7: article number 45017.

HAMMER Ø, HARPER DAT AND RYAN PD. 2001. PAST: Paleontological Statistics Software Package for education and data analysis. Palaeontol Electron 4(1): 1-9.

HEREDIA-ABARCA G, MENA-PORTALES J, MERCADOSIERRA A AND COLUMNA MG. 2013. Nuevos registros de hongos anamorfos tropicales asociados a restos vegetales para México. Rev Mex Micol 37: 69-81.

HERNÁNDEZ-GUTIÉRREZ A. 2013. New or rare fungi from Eastern Amazonia. 1. Circinoconiopsis amazonica gen. and sp. nov. Mycotaxon 123: 107-111.

HERNÁNDEZ-GUTIÉRREZ A, MONTEIRO JS AND SOTÃO HMP. 2009. Hifomicetos (fungos anamorfos) associados a palmeiras na Floresta Nacional de Caxiuanã, PA, Brasil. In: Lisboa P (Org), Caxiuanã: Desafios para a conservação de uma floresta nacional na Amazônia. Belém: Museu Paraense Emílio Goeldi, p. 397-405.

HUGHES SJ. 1951. Studies on micro-fungi. X. Zygosporium. Mycol Papers 44: 1-18.

HUGHES SJ. 1952. Fungi from the Gold Coast. I. Mycol Papers 48: 1-91.

HYDE KD, BUSSABAN B, PAULUS B, CROUS PW, LEE S, MCKENZIE EHC, PHOTITA W AND LUMYONG S. 2007. Diversity of saprobic microfungi. Biodiversity Conserv 16: 7-35.

HYDE KD ET AL. 2013. Families of Dothideomycetes. Fungal Diversity 63: 1-313.

ICMBIO- INSTITUTO CHICO MENDES DE CONSERVAÇÃO DA BIODIVERSIDADE. 2014. Plano de Manejo da Floresta Nacional do Amapá. Volume I Diagnóstico. Macapá: ICMBio, 222 p.

KODSUEB R, MCKENZIE EHC, LUMYONG S AND HYDE KD. 2008. Fungal succession on woody litter of Magnolia liliifera (Magnoliaceae). Fungal Divers 30: 55-72.

KRUSKAL JB. 1964. Nonmetric multidimensional scaling: a numerical method. Psychometrika 29: 115-129. 
LODGE DJ, CANTRELL SA AND GONZÁLEZ G. 2014. Effects of canopy opening and debris deposition on fungal connectivity, phosphorus movement between litter cohorts and mass loss. For Ecol Manage 332: 11-21.

MA Y, FILLEY TR, SZLAVECZ K AND MCCORMICK MK. 2014. Controls on wood and leaf litter incorporation into soil fractions in forests at different successional stages. Soil Biol Biochem 69: 212-222.

MAHARACHCHIKUMBURA SSN ET AL. 2015. Towards a natural classification and backbone tree for Sordariomycetes. Fungal Divers 72: 199-301.

MARTÍNEZ-RIVERA K, HEREDIA G, ROSIQUE-GIL E AND CAPPELLO S. 2014. Hongos anamorfos asociados a restos vegetales del Parque Estatal "Agua Blanca", Macuspana, Tabasco, México. Acta Bot Mex 107: 99-119.

MATSUSHIMA T. 1993. Matsushima Mycological Memoirs No. 7. Kobe, Published by the Author, $141 \mathrm{p}$.

MELO M, ARAUJO ACV, CHOGI MAN AND DUARTE ICS. 2018. Cellulolytic and lipolytic fungi isolated from soil and leaf litter samples from the Cerrado (Brazilian Savanna). Rev Biol Trop 66(1): 237-245.

MERCADO-SIERRA A, GENE J, FIGUERAS MJ, RODRIGUEZ K AND GUARRO J. 1998. New or rare Hyphomycetes from Cuba. IX. Some species from Pinar del Rio. Mycotaxon 68: 417-426.

MONTEIRO JS, CARMO LT AND SOTÃO HMP. 2017. A new species of Bhatia (asexual ascomycetes) and new records from Brazil. Phytotaxa 331(2): 263-272.

MONTEIRO JS, CASTAÑEDA-RUIZ RF AND GUSMÃO LFP. 2016a. Thozetella coronata and T. ypsiloidea spp. nov. from the Brazilian Amazon forest. Mycotaxon 131: 605-611.

MONTEIRO JS AND GUSMÃO LFP. 2014. Two new species of Ceratosporella (anamorphic fungi) from Brazilian Amazon forest. Nova Hedwigia 98(3-4): 481-490.

MONTEIRO JS, GUSMÃO LFP AND CASTAÑEDA-RUIZ RF. 2016b. Pleurothecium bicoloratum \& Sporidesmiopsis pluriseptata spp. nov. from Brazil. Mycotaxon 131: 145152.

MONTEIRO JS, HERNÁNDEZ-GUTIÉRREZ A AND SOTÃO HMP. 2010. Fungos anamorfos (hyphomycetes) da Floresta Nacional de Caxiuanã, Pará, Brasil. Novos registros para o Neotrópico. Acta Bot Bras 24(3): 868-870.

MONTEIRO JS, HERNÁNDEZ-GUTIÉRREZ A, SOTÃO HMP AND GRANDI RAP. 2013. Fungos conidiais decompositores ocorrentes em palmeiras e liquens associados na Floresta Nacional de Caxiuanã. In: Lisboa PLB (Org), Caxiuanã: Paraíso ainda preservado. Belém: Editora do Museu Paraense Emílio Goeldi, p. 341-366.

MOREAU C. 1947. Un Cercospora parasite des feuilles du palier à huile au Moyen Congo. Revue Mycologie 12: 3739.
MORGAN-JONES G, SINCLAIR RC AND EICKER A. 1991. Notes on hyphomycetes. LXII. Concerning Chloridium virescens var. allantosporum, a new taxon, C. virescens var. caudigerum, and Chloridium phaeosporum, from Southern Africa. Mycotaxon 41(2): 459-468.

MUELLER RC, RODRIGUES JLM, NUSSLEIN K AND BOHANNAN BJM. 2016. Land use change in the Amazon rain forest favours generalist fungi. Funct Ecol 30(11): 1845-1853.

MYCOBANK. 2018. Available at: http://www.mycobank. org/. Accessed on April 24, 2018.

NEERGAARD E, LYSHEDE OB, GAHOONIA TS, CARE D AND HOOKER JE. 2000. Anatomy and histology of roots and root-soil boundary. In: Smit AL, Bengough AG, Engels C, Noordwijk M, Pellerin S and Geijn SC (Eds), Root Methods: A Handbook. Berlin: Springer-Verlag, p. 33-73.

OSONO T AND TAKEDA H. 2002. Comparison of litter decomposing ability among diverse fungi in a cool temperate deciduous forest in Japan. Mycologia 94: 421427.

OSONO T AND TAKEDA H. 2006. Fungal decomposition of Abies needle and Betula leaf litter. Mycologia 98: 172-179.

PEAY KG, BARALOTO C AND FINE PVA. 2013. Strong coupling of plant and fungal community structure across Western Amazonian rainforests. The ISME Journal 7: 1852-1861.

PETRINI O AND DREYFUSS M. 1981. Endophytische Pilze en Epiphytischen Araceae, Bromeliaceae und Orchidaceae. Sydowia 38: 216-234.

PINNOI A, LUMYONG S, HYDE KD AND JONES EBG. 2006. Biodiversity of fungi on the palm Eleiodoxa conferta in Sirindhorn peat swamp forest, Narathiwat, Thailand. Fungal Divers 22: 205-218.

PINRUAN U, HYDE KD, LUMYONG S, MCKENZIE EHC AND JONES EBG. 2007. Occurrence of fungi on tissues of the peat swamp palm Licuala longicalycata. Fungal Divers 25: 157-173.

POLISHOOK JD, BILLS GF AND LODGE DJ. 1996. Microfungi from decaying leaves of two rain forest trees in Puerto Rico. J Ind Microbiol Biot 17(3/4): 284-294.

POLL C, BRUNE T, BEGEROW D AND KANDELER E. 2010. Small-scale diversity and succession of fungi in the detritusphere of Rye Residues. Microb Ecol 59: 130-140.

PPBIO - PROGRAMA DE PESQUISA EM BIODIVERSIDADE AMAZÔNIA ORIENTAL. 2018. Disponível em: http://ppbio.museu-goeldi.br/. Acesso em 25 de fevereiro de 2018.

PROMPUTTHA I, MCKENZIE EHC, TENNAKOON DS, LUMYONG S AND HYDE KD. 2017. Succession and natural occurrence of saprobic fungi on leaves of Magnolia liliifera in a tropical forest. Cryptogamie Mycol 38(2): 213-225. 
PURAHONG W, WUBET T, LENTENDU G, SCHLOTER M, PECYNA MJ, KAPTURSKA D, HOFRICHTER M, KRÜGER D AND BUSCOT F. 2016. Life in leaf litter: novel insights into community dynamics of bacteria and fungi during litter decomposition. Mol Ecol 25(16): 40594074.

RODRIGUES K. 1994. The foliar fungal endophytes of the Amazonian palm Euterpe oleracea. Mycologia 86(3): 376-385.

SANTA IZABEL TS AND GUSMÃO LFP. 2018. Richness and diversity of conidial fungi associated with plant debris in three enclaves of Atlantic Forest in the Caatinga biome of Brazil. Plant Ecol Evol 151(1): 35-47.

SANTANA ME, LODGE DJ AND LEBOW P. 2005. Relationship of host recurrence in fungi to rates of tropical leaf decomposition. Pedobiologia 49: 549-564.

SANTOS MVO, BARBOSA FR, LUZ EDMN AND BEZERRA JL. 2017. Fungos conidiais em folhedo de Mata Atlântica na Reserva Biológica de Una, Bahia, Brasil. Agrotrópica 29(3): 195-202.

SEEPHUEAK P, PHONGPAICHIT S, HYDE KD AND PETCHARAT V. 2011. Diversity of saprobic fungi on decaying branch litter of the rubber tree (Hevea brasiliensis). Mycosphere 2(4): 307-330.

SEIFERT K, MORGAN-JONES G, GAMS W AND KENDRICK B. 2011. The Genera of Hyphomycetes. CBS Biodiversity Series no. 9. Utrecht: CBS-KNAW Fungal Biodiversity Centre, 997 p.
SILVA M AND MINTER DW. 1995. Fungi from Brasil. Recorded by Batista and co-workers. Mycol Papers 169: $1-585$.

SILVA SS, SILVA CR, GUSMÃO LFP AND CASTAÑEDARUIZ RF. 2015. A new species of Chaetochalara on decaying leaves from Brazil. Mycotaxon 130: 505-509.

STEEGE H ET AL. 2013. Hyperdominance in the Amazonian tree flora. Science 342(6156): 1243092.

SUTTON BC AND HODGES CS. 1976. Eucalyptus microfungi: some setose hyphomycetes with phialides from Malaysia. Nova Hedwigia 27: 343-347.

VOŘÍŠKOVÁ J AND BALDRIAN P. 2013. Fungal community on decomposing leaf litter undergoes rapid successional changes. ISME J 7: 477-486.

WHITTON SR, MCKENZIE EHC AND HYDE KD. 2003. Microfungi on the Pandanaceae: Zygosporium, a review of the genus and two new species. Fungal Divers 12: $207-$ 222.

WU YM AND ZHANG TY. 2013. A new species and new record of Chloridium from the Qinghai-Tibet Plateaeu Area, China. Mycotaxon 123: 277-280.

YANNA WHH AND HYDE KD. 2002. Fungal succession on fronds of Phoenix hanceana in Hong Kong. Fungal Divers 10: $185-211$.

YANNA WHH, HYDE KD AND GOH TK. 2001. Occurrence of fungi on tissues of Livistona chinensis. Fungal Divers 6: $167-180$.

ZAR JH. 2009. Biostatistical analysis. $5^{\text {th }}$ ed., San Francisco: Prentice Hall, 756 p. 